\title{
Biological Quality Indicators of a Haplortox Soil Under Different Management Systems in Southern Brazil
}

\author{
Macarius Cesar Di Lauro Moreira ${ }^{1}$, Deonir Secco ${ }^{1}$, Luiz Antônio Zanão Júnior ${ }^{2}$, Luciene Kazue Tokura ${ }^{1}$, \\ Araceli Ciotti de Marins ${ }^{3}$, Maurício Antônio Pilatti ${ }^{1} \&$ Bruna de Villa ${ }^{4}$ \\ ${ }^{1}$ State University of West Paraná (UNIOESTE), Post-Graduation Program, Master's in Engineering of Energy in \\ Agriculture, Cascavel, Paraná, Brazil \\ ${ }^{2}$ Agronomic Institute of Paraná (IAPAR), Santa Tereza do Oeste, Paraná, Brazil \\ ${ }^{3}$ Department of Mathematics, Federal Technological University of Paraná (UTFPR), Toledo, Paraná, Brazil \\ ${ }^{4}$ State University of West Paraná (UNIOESTE), Graduation in Engineering Agricultural, Cascavel, Paraná, Brazil \\ Correspondence: Macarius Cesar Di Lauro Moreira, State University of West Paraná (UNIOESTE), Rua \\ Universitária, 2069, Jardim Universitário, CEP: 85819-110, Cascavel, Paraná, Brazil. Tel: 55-(45)-3220-3151. \\ E-mail: macariusdilauro@hotmail.com
}

Received: January 30, 2018

doi:10.5539/jas.v10n5p250
Accepted: March 14, $2018 \quad$ Online Published: April 15, 2018

URL: https://doi.org/10.5539/jas.v10n5p250

\begin{abstract}
The research was looking for the quick response of soil's microbiota to soil changes caused by management systems, changes to which biological indicators of soil quality are sensitive. In this context, this study aimed to evaluate the impacts of seven soil management systems, including in on hand covers of Pennisetum glaucum (PG), Avena strigosa (AS), Stizolobium aterrimum (SA), EF Pisum sativum (PS) + Avena strigosa (AS), and on the other hand, No soil tillage with gypsum application (NTSG), No soil tillage with scarification (NTSS) and No soil tillage (NTS), on soil quality bioindicators. The bioindicators recorded from top soil samples were collected from the first $10 \mathrm{~cm}$ at pre-planting, at pre-flowering and at post-harvest of the soybean, from July 2014 to March 2015 were Total organic carbon (TOC), Soil microbial biomass carbon (SMBC), Soil basal respiration, Respiratory coefficient $\left(q \mathrm{CO}_{2}\right)$, Microbial coefficient $(q \mathrm{MIC})$, and its relationship with soybean yields. The seven treatments were arranged in the field according to a completely randomized experimental, Analysis of variance (Anova) for each of the bioindicators and comparison of treatment mean values using Tukey test at $5 \%$ probability were carried out. SA, the AS+PS consortium and the no-tillage system led to significant improvement of the biological attributes of the soil. The management systems did not change the yield of soybean grain.
\end{abstract}

Keywords: soil microbial biomass carbon, soil organic matter, soybean yield

\section{Introduction}

The soil microbiota is responsible of the maintenance of ecosystems through their action in the biogeochemical cycles, as well as their performance in soil formation and structuring, nutrient cycling and organic matter decomposition (Souza et al., 2006).

The productivity of a crop is directly proportional to the amount of microbial biomass of the soil, microbial population and activity are altered according to the soil management, in some cases, having a deleterious effect on it, and thus, considered an important soil quality indicator (Perez, Ramos, \& McManus, 2004; Legaz et al., 2017).

Currently, the use of green manure in a no-tillage system has become increasingly important for the improvement of the soil's biological, physical and chemical attributes. These species must possess high resistance to temperature variations and rainfall levels, roots with high vigor, ease of elimination and non-competition with the subsequent crop, to cycle nutrients (Dessalew et al., 2017), among others; for these reasons, the two main groups of cover plants are the Fabaceae (leguminous plants) and the Poaceae (grasses) (Foloni, Lima, \& Bull, 2006; Carneiro et al., 2008). 
Representatives of the Fabaceae family have their use established because they reincorporate nitrogen to the soil that is fixed biologically through the bacteria of the Rhizobium and Bradyrhizobium genera, in addition to their high rate of decomposition resulting from the low value of the $\mathrm{C} / \mathrm{N}$ ratio, which is less than 20 , thus rapidly cycling nutrients (Carneiro et al., 2008).

The high $\mathrm{C} / \mathrm{N}$ ratio of Poaceae family members, which varies between 30 and 40, guarantees their greater permanence in the soil, contributing to a greater protection of the soil with the formation of straw, which also acts as a reserve of nutrients with slow degradation and; its abundant roots act directly on the soil structure, maintaining the stabilization of the aggregates (Carneiro et al., 2008).

In this scenario, the cultivation of cover crops increases its importance in the soil, since they soften the physical, chemical and biological alterations that the soils undergo at each crop (Silva et al., 2010).

Studies have demonstrated that microbial biomass and its activity act as more sensitive indicators to changes in soil structure and quality, caused by soil management systems (Trannin, Siqueira, \& Moreira, 2007).

The objective of this study was to evaluate the impact of seven different management systems on microbiological attributes of soil quality and its effects on soybean yield.

\section{Material and Methods}

\subsection{Experimental Area and Soil}

The research was carried out at the experimental station of the Agronomic Institute of Paraná (IAPAR), located in the municipality of Santa Tereza do Oeste, Paraná State. The region's geographical coordinates are longitude $53^{\circ} 29^{\prime} 37^{\prime \prime} \mathrm{W}$ and latitude $24^{\circ} 50^{\prime} 42^{\prime \prime} \mathrm{S}$. Its altitude is $750 \mathrm{~m}$ above sea level and climatic classification, according to Koppen, is humid subtropical (cfa). The annual average precipitation is $1840 \mathrm{~mm}$. The soil is classified as typical Haplortox with a clay texture, smooth-wavy terrain, and basalt substrate as well (Embrapa, 2013).

\subsection{Field Establishment of the Experiment}

As treatments, three soil management systems were used in an area managed with no soil tillage for 18 years (no-tillage system-NTS; no-tillage system with gypsum application-NTSG and no-tillage system with scarification-NTSS) and four other treatments with cover plant species: consortium with Avena strigosa (AS) and Pisum sativum subsp. arvense (PS); Avena strigosa (AP); Pennisetum glaucum (PG) and Stizolobium aterrimum (SA). A seed-fertilizer was used with lagged double-disc type trencher mechanism, with no base fertilization and/or coverage for the planting of cover plant species (Table 1). Treatments arrangement is shown in Figure 1.

Table 1. Timetable of field activities

\begin{tabular}{ll}
\hline Dates & Activities \\
\hline $3 / 27 / 2014$ & Seeding of summer cove plant species \\
$7 / 17 / 2014$ & Seeding of winter cover plant species \\
$7 / 10 / 2014$ & Application of gypsum (1 application) \\
$10 / 20 / 2014$ & Soil scarification (1 scarification) \\
$11 / 7 / 2014$ & Soybean seeding \\
$3 / 11 / 2015$ & Soybean harvest \\
\hline
\end{tabular}

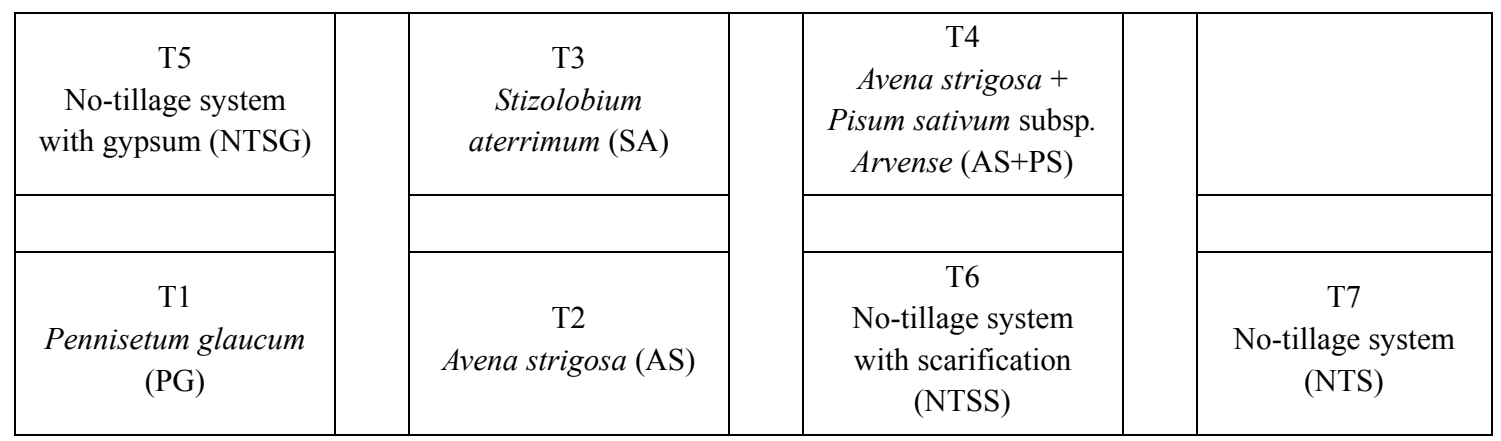

Figure 1. Sketch of the experimental area and arrangement of treatments. The experimental units consisted of plots of $20 \mathrm{~m} \times 25 \mathrm{~m}$ 
The no-tillage system with gypsum consisted of the application of $3000 \mathrm{~kg} \mathrm{ha}^{-1}$ of gypsum on the surface. In the no-tillage system with scarification, the scarification was up to $0.30 \mathrm{~m}$ deep.

Cultural practices for the control of weeds (N-(phosphonomethyl)-glycin $-4 \mathrm{~L} \mathrm{ha}^{-1}$ ), pests (Bifenthrin + carbosulfan $-0.3 \mathrm{~L} \mathrm{ha}^{-1}$ ) and diseases (fluxapyroxad + pyraclostrobin- $0.3 \mathrm{~L} \mathrm{ha}^{-1}+$ Soy oil methyl ester $0.25 \%$ v.v.) were carried out in the according to technical recommendations for soybean culture, using a tractor/hydraulic sprayer set with a capacity of $600 \mathrm{~L}$ and $14 \mathrm{~m}$-spray bar. Soil fertilization was carried out with $300 \mathrm{~kg} \mathrm{ha}^{-1}$ of NPK formulation 02-20-20. 16 seeds per linear meter of cultivar Vmax NK 7059 RR of soy were sown in rows with $0.45 \mathrm{~m}$ spacing.

The experimental design was completely randomized design. Soil samples were collected in three periods: pre-planting, pre-flowering and post-harvesting of soybean, from July 2014 to March 2015, in four replications for each experimental plot, totaling 12 samples in each treatment.

Samples for microbiological analysis of the soil and the soil's biota respiratory activity were collected in the $0-0.10 \mathrm{~m}$ layer at three randomly selected sites, where the vegetable material layer was removed. The soil was collected with a paddle and conditioned in $0.10 \mathrm{~m} \times 0.25 \mathrm{~m}$ plastic containers suitable for the collection of soil samples, which were transferred immediately after collection to the laboratory for processing and storage in a refrigerator at $4{ }^{\circ} \mathrm{C}$.

\subsection{Variables Determined}

The determination of total organic carbon (TOC) was done according to the Walkley-Black technique (Embrapa, 1999).

The values referring to the soil microbial biomass carbon (SMBC) were obtained according to the protocol for the Fumigation - Extraction methodology (Embrapa, 2007).

The soil's basal respiration (SBR) was evaluated following the protocol described by Embrapa (1999).

The metabolic coefficient $\left(q \mathrm{CO}_{2}\right)$ is the ratio between SBR and SMBC, expressed in $\mathrm{mg} \mathrm{C}-\mathrm{CO}_{2} \mathrm{~g} \mathrm{Cmic} \mathrm{h}^{-1}$, defined by the formula:

$$
\left(q \mathrm{CO}_{2}\right)=\mathrm{SBR} / \mathrm{SMBC}
$$

Where, $\mathrm{SBR}=\mathrm{C}-\mathrm{CO}_{2}=$ Value of basal respiration; $\mathrm{SMBC}=$ Carbon value of soil microbial biomass .

The microbial quotient $(q \mathrm{MIC})$ is the ratio between SMBC and TOC, expressed as a percentage, calculated according to the formula:

$$
(q \mathrm{MIC})=\mathrm{SMBC} / \mathrm{TOC}
$$

Where, $\mathrm{SMBC}=$ Carbon value of soil microbial biomass; $\mathrm{TOC}=$ Total organic carbon

For soybean yield, grains were collected from 4 rows of 2.5 meters, totaling $4.5 \mathrm{~m}^{2}$ with four replications per plot. The harvest was carried out with a plot harvester, and the moisture was corrected to $13 \%$.

\subsection{Statistical Analysis}

Statistical analysis was performed using Assistat ${ }^{\circledR} 7.6$ beta software, 2012 version (Silva, 2012). The analysis carried out was: an analysis of variance (Anova) for TOC, SMBC, BSR, $q \mathrm{CO} 2$, and $q \mathrm{MIC}$ and a comparison of treatment mean values for the above parameters measured using Tukey test at $5 \%$ probability.

\section{Results and Discussion}

\subsection{Microbiological Soil Properties and Soybean Yield}

The average values of microbiological soil properties between management systems and coverage species are shown in Table 2.

No statistically significant differences were found for TOC in management systems (Table 2). This lack of difference probably occurs when the soil has living vegetation coverage, where the soil temperature becomes more constant and there is less water loss from the soil to the atmosphere, thus maintaining the organic carbon, avoiding it from being lost in the form of $\mathrm{CO}_{2}$ to the atmosphere (Barros, 2013).

The higher TOC values refer to the condition of environmental stability of the soil that the coverage, in the living case, provides; such as decrease of thermal and humidity variations, as well as a more favorable environment for the proliferation of the microorganisms than the period with the straw alone and after mechanization of the area (Barros, 2013). 
Table 2. Average values of three seasons evaluated for the microbiological soil properties between management systems and coverage species

\begin{tabular}{|c|c|c|c|c|c|c|c|c|c|c|}
\hline \multirow{2}{*}{ Biological attributes } & \multicolumn{10}{|c|}{ Treatments } \\
\hline & PG & AS & SA & $\mathrm{AS}+\mathrm{PS}$ & NTSG & NTSS & NTS & LSD & Average & CV (\%) \\
\hline TOC $\left(\mathrm{g} \mathrm{kg}^{-1}\right)$ & $31.2 \mathrm{a}$ & $29.1 \mathrm{a}$ & $31.2 \mathrm{a}$ & $31.0 \mathrm{a}$ & $31.3 \mathrm{a}$ & $29.7 \mathrm{a}$ & $30.7 \mathrm{a}$ & 3.67 & 30.61 & 9.69 \\
\hline SMBC (mg C g ${ }^{-1}$ soil) & $99.3 b$ & $76.7 \mathrm{~b}$ & $198.5 \mathrm{a}$ & $173.15 \mathrm{a}$ & $96.47 \mathrm{~b}$ & $158.34 \mathrm{a}$ & $173.57 \mathrm{a}$ & 54.34 & 177.37 & 31.55 \\
\hline BSR (mg C-CO ${ }_{2} \mathrm{~g}^{-1}$ soil $\left.\mathrm{h}^{-1}\right)$ & $0.65 \mathrm{a}$ & $1.17 \mathrm{a}$ & $1.08 \mathrm{a}$ & $0.84 \mathrm{a}$ & $1.46 \mathrm{a}$ & $1.14 \mathrm{a}$ & $1.00 \mathrm{a}$ & 1.16 & 1.74 & 89.36 \\
\hline$q \mathrm{CO}_{2}\left(\mathrm{mg} \mathrm{C}-\mathrm{CO}_{2} \mathrm{mg}^{-1} \mathrm{cbms} \mathrm{h}^{-1}\right)$ & $6.43 b c$ & $15.58 \mathrm{a}$ & $4.80 \mathrm{c}$ & $4.80 \mathrm{c}$ & $14.8 \mathrm{ab}$ & $6.20 \mathrm{bc}$ & $6.31 \mathrm{bc}$ & 8.80 & 18.21 & 84.59 \\
\hline$q \mathrm{MIC}\left(\mathrm{mg} \mathrm{g}^{-1} q \mathrm{mic}\right)$ & $32.29 b$ & $26.74 b$ & $65.24 \mathrm{a}$ & $55.45 \mathrm{a}$ & $31.79 \mathrm{~b}$ & $53.81 \mathrm{a}$ & $57.68 \mathrm{a}$ & 20.69 & 68.40 & 36.31 \\
\hline
\end{tabular}

Note. Averages of treatments followed by the same letter in the row do not differ statistically from each other by the Tukey test at the 5\% level of significance. PG: Pennisetum glaucum, AS: Avena strigosa, SA: Stizolobium aterrimum, AS+PS: Avena strigosa + Pisum sativum, NTSG: No-tillage system with gypsum, NTSS: No-tillage system with scarification, NTS: No-tillage system, LSD: Least Significant Difference, CV: Coefficient of Variation (\%), TOC: total organic carbon, SMBC: microbial biomass carbon of the soil, BSR: basal respiration of the soil, $q \mathrm{CO}_{2}$ : respiratory coefficient, $q \mathrm{MIC}$ : microbial coefficient.

Pereira et al. (2010) state that TOC is a sensitive indicator to changes in the micro habitats of the soil, through the alteration in the management systems; in treatments with coverage, they provide their TOC increase and reduction in the absorption of phosphorus from the soil. Increased soil mobilization reduces carbon stocks and when Pennisetum glaucum (PG) is used as coverage, it generates a deeper incorporation of carbon into the soil.

In the studies by Cunha et al. (2011), in treatments with coverage plants in bean and corn crops, there were no statistical differences between the management systems regarding soil TOC content, in the $0.00-0.10 \mathrm{~m}$ layer, data which is also evidenced in the work by Almeida et al. (2008), where it covered the soil for three years in the following systems: fallow, Crotalaria juncea, Cajanus cajan, Pisum sativum and Pennisetum glaucum, and Sousa Neto, Andrioli, and Beutler (2008), analyzing Crotalaria juncea, Pennisetum glaucum and lablabe (Dolichus lablab) in a period of four years.

There is a statistical difference for the SMBC indicator, and the treatment that had the highest SA with $198.5 \mathrm{mg}$ $\mathrm{C} \mathrm{g}^{-1}$ dry soil and the lowest AS value with $76.7 \mathrm{mg} \mathrm{C} \mathrm{g}^{-1}$ dry soil. As expected, since the representatives of the fabaceae family provides the SMBC elevation of the soil, due to symbiotic associations in its roots. Duarte et al. (2014), in their studies with biological indicators of soil quality and coverage plants, verified that the highest value of SMBC was recorded in the treatment with Crotalaria juncea, however, finding values close to the other coverages. Cultural residues at the soil surface increase substrate availability, higher water availability, lower thermal amplitude, providing a more stable and favorable environment to BMS (Castro-Filho et al., 2002; Franchini et al., 2007; Bayer et al., 2002; Pereira et al., 2007). Several studies refer to the beneficial effects of legumes for the enrichment of SMBC in soil, due to its $\mathrm{N}_{2}$ biofixation capacity (Ferreira et al., 2000; Franchini et al., 2007).

For SBR there was no significant statistical difference between treatments. Alves et al. (2011), Cunha et al. (2011), Duarte et al. (2014), and Dadalto et al. (2015) found no significant differences between management systems and this biological attribute. However, Nascimento et al. (2009) found significant differences between management systems. Carneiro et al. (2008), studying management systems with different coverages, high values of $q \mathrm{CO}_{2}$ were observed in the uncovered system, demonstrating, in this area, the loss of carbon in the form of $\mathrm{CO}_{2}$ to the atmosphere, characterizing stress in the microbial population, however, the areas covered with residues of Crotalaria juncea and Cajanus cajan had the lowest values of $q \mathrm{CO}_{2}$, characterizing a beneficial effect from the residues of these coverages for the microbial population of the soil.

There was statistical difference for the $q \mathrm{CO}_{2}$, where the highest value was that of treatment AS $15.58 \mathrm{mg} \mathrm{C}-\mathrm{CO}_{2}$ $\mathrm{mg}^{-1} \mathrm{SMBC} \mathrm{h}{ }^{-1}$ and the lowest was that of treatments SA and EF, both with $4.8 \mathrm{mg} \mathrm{C}-\mathrm{CO}_{2} \mathrm{mg}^{-1} \mathrm{SMBC} \mathrm{h}^{-1}$. High $q \mathrm{CO}_{2}$ values represent disturbances or stress in the ecosystems (Bardgett, \& Saggar, 1994). In a study in which they evaluated several species of coverage and their action on BMS, Carneiro et al. (2008), noticed high values of $q \mathrm{CO}_{2}$ in the fallow management, demonstrating the loss of carbon in the form of $\mathrm{CO}_{2}$ to the atmosphere, characterizing stress in the soil biota.

For the $q \mathrm{MIC}$ attribute there was difference, with the highest value being verified in the SA $65.24 \mathrm{mg} \mathrm{g}^{-1} q \mathrm{MIC}$ and the lowest in the AS $26.74 \mathrm{mg} \mathrm{g}^{-1} q \mathrm{MIC}$. High values of $q$ MIC characterize high levels of organic carbon in the soil, and low values demonstrate soil carbon loss over a given period (Mercante et al., 2004). The $q \mathrm{MIC}$ is 
influenced by several factors, such as the management history in the study area and the degree of stabilization of organic C (Silva et al. 2010). Cunha et al. (2011) observed the highest value of $q \mathrm{MIC}$ in the treatment with Pisum sativum and Stizolobium aterrimum in relation to crotalaria and fallow.

Several studies have shown that green coverages with legumes associated with low soil mobilization lead to increased contents of SMBC (Franchini et al., 2007).

The Stizolobium aterrimum is indicated to be used as green manure due to its characteristic of improving the fertility and texture of the soil and by its inhibitory effect of nematode species (Ferraz et al., 2003).

Average values of soybean yield $\left(\mathrm{Mg} \mathrm{ha}^{-1}\right)$ in management systems and soil coverage species in Table 3 .

Table 3. Average values of soybean yield $\left(\mathrm{Mg} \mathrm{ha}^{-1}\right)$ in management systems and soil coverage species

\begin{tabular}{llllllllll}
\hline \multicolumn{10}{c}{ Treatments } \\
\hline PG & AS & SA & AS+PS & NTSG & NTSS & NTS & LSD & Average & CV $(\%)$ \\
$3.02 \mathrm{a}$ & $2.96 \mathrm{a}$ & $2.70 \mathrm{a}$ & $2.86 \mathrm{a}$ & $2.91 \mathrm{a}$ & $2.93 \mathrm{a}$ & $2.67 \mathrm{a}$ & 573.7 & 2.81 & 87.1 \\
\hline
\end{tabular}

Note. Averages of treatments followed by the same letter in the row do not differ statistically from each other by the Tukey test at the 5\% level of significance. PG: Pennisetum glaucum, AS: Avena strigosa, SA: Stizolobium aterrimum, AS+PS: Avena strigosa + Pisum sativum, NTSG: No-tillage system with gypsum, NTSS: No-tillage system with scarification, NTS: No-tillage system, LSD: Least Significant Difference, CV: Coefficient of Variation (\%).

Even before the improvement of the soil's biological attributes, the yield of soybean grains did not present statistical difference between the treatments (Table 3).

Pereira et al. (2011) observed in a typical eutrophic Red Latosol, where they applied Avena strigosa and Pennisetum glaucum as coverage, that there were no statistical differences for the yield of soybeans between the straw desiccation seasons. Ricce, Alves, and Prete (2011), in a study on a dystroferric Red Latosol, whose areas were covered with grazing, Avena strigosa and ryegrass, found no difference in soybean grains yield.

In the studies by Santos et al. (2014), in area with coverage plants, no difference was observed in the soybean grain yield during the period when the study was carried out, 1996/1997 to 2010/2011.

Santos et al. (2013), found no significant difference between coverage plants, as for the grain yield, however, after the vetch crop, the soybeans that were planted obtained the highest number of pods, number of grains and grain mass per plant than those that were sown in the other systems. Brancalião et al. (2015) statistically demonstrated that, in areas with coverage, the grain yield was higher than the areas left in fallow, stating that the fact that the soil coverage in winter alone already provides gains in soybean productivity. The differences were not observed in the soybean productivity, probably for two reasons: first, because the study area is an experimental station, the soil is maintained under high levels of fertilization; the second probable reason was the occurrence of a high and constant rainfall index in the region during the soybean development cycle.

\section{Conclusion}

Stizolobium aterrimum (SA), the Avena strigosa (AS) + Pisum sativum (PS) consortium and the no-tillage system (NTS) are the most indicated species and system for the improvement of the biological attributes of the soil; To increase the TOC of the soil, we recommend the use of the treatments: Pennisetum glaucum (PG), SA, AS+PS and NTS; There was a soil microbial biomass carbon (SMBC) increase in the treatments: SA, AS+PS, NTS and no-tillage system with scarification (NTSS); To reduce soil basal respiration (SBR), the most suitable treatments are PG, PS, NTS, NTSS and AS; In the respiratory coefficient $\left(q \mathrm{CO}_{2}\right)$ the SA, the AS+PS consortium and the TSS had lower values in the three evaluated periods; To increase the microbial coefficient $(q \mathrm{MIC})$ the recommended treatments were SA, AS+PS, NTS and NTSS.

Species and management systems did not interfere with the soybean grain yield.

\section{References}

Almeida, V. P., Alves, M. C., Silva, E. C., \& Oliveira, A. S. (2008). Rotação de culturas e propriedades físicas e químicas em Latossolo Vermelho de cerrado sob preparo convencional e semeadura direta em adoção. Revista Brasileira de Ciência do Solo, 32, 1227-1237. https://doi.org/10.1590/S0100-06832008000300031 
Alves, T. D. S., Campos, L. L., Elias Neto, N., Matsuoka, M., \& Loureiro, M. F. (2011). Biomassa e atividade microbiana de solo sob vegetação nativa e diferentes sistemas de manejos. Acta Scientiarum. Agronomy, 33(2), 341-347. https://doi.org/10.4025/actasciagron.v33i2.4841

Bardgett, R. D., \& Saggar, S. (1994). Effects of heavy metal contamination on the short-term decomposition of labeled [14C] glucose in a pasture soil. Soil Biology and Biochemistry, 26(6), 727-733. https://doi.org/ 10.1016/0038-0717(94)90265-8

Barros, J. S. (2013). Contribuições da matéria orgânica do solo para mitigar as emissões agrícolas de gases de efeito estufa. Polêmica, 12(2), 341-351. Retrieved from http://www.e-publicacoes.uerj.br/index.php/ polemica/article/view/6436/4862

Bayer, C., Mielniczuk, J., Martin-Neto, L., \& Ernani, P. R. (2002). Stocks and humification degree of organic matter fractions as affected by no-tillage on a subtropical soil. Plant and Soil, 238, 133-140. https://doi.org/10.1023/A:1014284329618

Brancalião, S. R., Aguiar, A. T. E., Brancalião, E. M., Limonta, C. R., Rossi, C. E., \& Cristovão, N. N. (2015). Produtividade e composição dos grãos de soja após o aporte de nitrogênio com o uso de culturas de cobertura em sistema de semeadura direta. Nucleus, 12(1), 69-75. https://doi.org/10.37378/1982.2278.1001

Carneiro, M. A. C., Cordeiro, M. A. S., Assis, P. C. R., Moraes, E. S., Pereira, H. S., Paulino, H. B., \& Souza, E. D. (2008). Produção de fitomassa de diferentes espécies de cobertura e suas alterações na atividade microbiana de solo de cerrado. Bragantia, 67(2), 455-456. https://doi.org/10.1590/S0006-870520080002 00021

Castro Filho, C., Lourenço, A., Guimarães, M. F., \& Fonseca, I. C. B. (2002). Aggregate stability under diferent soil management systems in a red Latosol in the state of Parana, Brazil. Soil \& Tillage Research, 65(1), 45-51. https://doi.org/10.1016/S0167-1987(01)00275-6

Cunha, E. Q., Stone, L. F., Moreira, J. A. A., Ferreira, E. P. B., Didonet, A. D., \& Leandro, W. M. (2011). Sistemas de preparo do solo e culturas de cobertura na produção orgânica de feijão e milho. I-Atributos físicos do solo. Revista Brasileira de Ciência do Solo, 35, 589-602. https://doi.org/10.1590/S010006832011000200029

Dadalto, J. P., Fernandes, H. C., Teixeira, M. M., Cecon, P. R., \& Matos, A. T. (2015). Sistema de preparo do solo e sua influência na atividade microbiana. Revista Engenharia Agrícola, 35(3), 506-513. https://doi.org/ 10.1590/1809-4430-Eng.Agric.v35n3p506-513/2015

Dessalew, G., Beyene, A., Nebiyu, A., \& Ruelle, M. L. (2017). Use of industrial diatomite wastes from beer production to improve soil fertility and cereal yields. Journal of Cleaner Production, 157, 22-29. https://doi.org/10.1016/j.jclepro.2017.04.116

Duarte, I. B., Gallo, A. S., Gomes, M. S., Guimarães, N. F., Rocha, D. P., \& Silva, R. F. (2014). Plantas de cobertura e seus efeitos na biomassa microbiana do solo. Acta Iguazu, 3(2), 150-165. Retrieved from http://e-revista.unioeste.br/index.php/actaiguazu/article/view/10625

EMBRAPA (Empresa Brasileira de Pesquisa Agropecuária). (1999). Manual de Análises Químicas de Solos, Plantas e Fertilizantes. Centro Nacional de Pesquisa de Solos. Campinas: Embrapa Informática Agropecuária; Rio de Janeiro: Embrapa Solos.

EMBRAPA (Empresa Brasileira de Pesquisa Agropecuária). (2007). Determinação do Carbono da Biomassa Microbiana do Solo (BMS-C). Centro Nacional de Pesquisa de Solos. Seropédica, Rio de Janeiro: Embrapa.

EMBRAPA (Empresa Brasileira de Pesquisa Agropecuária). (2013). Manual de Métodos de Análise de solo (1st ed.). Centro Nacional de Pesquisa de Solos. Rio de Janeiro: Embrapa CNPS.

Ferraz, S., Lopes, E. A., Ferreira, P. A., Amora, D. X., Freitas, C. F., \& Campos, A. V. S. (2003). Efeito do cultivo de duas espécies de Mucuna sobre a população de Meloidogyne exiguia, M. incognita e M javanica. Nematologia Brasileira 27(2), 236-237.

Ferreira, M. C., Andrade, D. S., Chueire, L. M. O., Takemura, S. M., \& Hungria, M. (2000). Tillage method and crop rotation on the population sizes and diversity of bradryhizobia nodulating soybean. Soil Biology \& Biochemistry, 32, 627-637. https://doi.org/10.1016/S0038-0717(99)00189-3

Foloni, J. S. S., Lima, S. L., \& Bull, L. T. (2006). Crescimento aéreo e radicular da soja e de plantas de cobertura em camadas compactadas de solo. Revista Brasileira de Ciência do Solo, 30, 49-57. https://doi.org/10.1590/ S0100-06832006000100006 
Franchini, J. C., Crispino, C. C., Souza, R., Torres, E., \& Hungria, M. (2007). Microbiological parameters as indicators of soil quality under various tillage and crop-rotation systems in southern Brazil. Soil \& Tillage Research, 92(1), 18-29. https://doi.org/10.1016/j.still.2005.12.010

Legaz, B. V., Souza, D. M. de, Teixeira, R. F. M., Antón, A., Putman, B., \& Sala, S. (2017). Soil quality, properties, and functions in life cycle assessment: An evaluation of models. Journal of Cleaner Production, 140(2), 502-515. https://doi.org/10.1016/j.jclepro.2016.05.077

Mercante, F. M., Fabricio, A. C., Machado, L. A. Z., \& Silva, W. M. (2004). Parâmetros Microbiológicos Como Indicadores de Qualidade do Solo sob Sistemas Integrados de Produção Agropecuária. Boletim de Pesquisa e Desenvolvimento (p. 27). Dourados: Embrapa Agropecuária Oeste.

Nascimento, J. B., Carvalho, G. D., Cunha, E. Q., Ferreira, E. P. D. B., Leandro, W. M., \& Didonet, A. (2009). Determinação da biomassa e atividade microbiana do solo sob cultivo orgânico do feijoeiro-comum em sistemas de plantio direto e convencional após cultivo de diferentes espécies de adubos verdes. Revista Brasileira de Agroecologia, 4(2), 4240-4243. Retrieved from http://revistas.aba-agroecologia.org.br/ index.php/cad/article/view/5144

Pereira, A. A., Hungria, M., Franchini, J. C., Kaschuk, G., Chueire, L. M. O., Campo, R. J., \& Torres, E. (2007). Variações qualitativas e quantitativas na microbiota do solo e na fixação biológica do nitrogênio sob diferentes manejos com soja. Revista Brasileira de Ciência do Solo, 31(6), 1397-1412. https://doi.org/ $10.1590 / \mathrm{S} 0100-06832007000600017$

Pereira, M. G., Loss, A., Beutler, S. J., \& Torres, J. L. R. (2010). Carbono, matéria orgânica leve e fósforo remanescente em diferentes sistemas de manejo do solo. Pesquisa Agropecuária Brasileira, 45(5), 508-514. https://doi.org/10.1590/S0100-204X2010000500010

Pereira, R. A., Alves, P. L. C. A., Corrêa, M. P., \& Dias, T. C. S. (2011). Influência da cobertura de aveia preta e milheto sobre comunidade de plantas daninhas e produção de soja. Revista Brasileira de Ciências Agrárias, 6, 1-10. https://doi.org/10.5039/agraria.v6ila545

Perez, K. S., Ramos, M. L. G., \& McManus, C. (2004). Carbono da biomassa microbiana em solo cultivado com soja sob diferentes sistemas de manejo nos Cerrados. Pesquisa Agropecuária Brasileira, 39(6), 567-573. https://doi.org/10.1590/S0100-204X2004000600008

Ricce, W. S., Alves, S. J., \& Prete, C. E. C. (2011). Época de dessecação de pastagem de inverno e produtividade de grãos de soja. Pesquisa Agropecuária Brasileira, 46(10), 1220-1225. https://doi.org/10.1590/S0100204X2011001000015

Santos, H. P., Fontaneli, R. S., Pires, J., \& Lampert, E. A., Vargas, A. M., Verdi, A. C. (2014). Grain yield and agronomic traits in soybean according to crop rotation systems. Bragantia, 73(3), 263-273. https://doi.org/ $10.1590 / 1678-4499.0136$

Santos, H. P., Fontaneli, R. S., Spera, S. T., \& Maldaner, G. L. (2013). Rendimento de grãos e em diferentes sistemas de produção integração Lavoura-pecuária. Revista Brasileira de Ciências Agrárias, 8(1), 49-56. https://doi.org/10.5039/agraria.v8i1a2077

Silva, C. A. T. (2012). Porosidade de latossolos e praticas de manejo agrícola para a conservação do solo. Varia Scientia Agrárias, 2(2), 153-164. Retrieved from http://e-revista.unioeste.br/index.php/variascientiaagraria/ article/view/4087/5054

Silva, R. R., Silva, M. L. N., Cardoso, E. L., Moreira, F. M. S., Curi, N., \& Alovisi, A. M. T. (2010). Biomassa e atividade microbiana em solo sob diferentes sistemas de manejo na região fisiográfica Campos das Vertentes-MG. Revista Brasileira de Ciência do Solo, 34(5), 1585-1592. https://doi.org/10.1590/S010006832010000500011

Sousa Neto, E. L., Andrioli, I., \& Beutler, N. A. (2008). Atributos físicos do solo e produtividade de milho em resposta a culturas de pré-safra. Pesquisa Agropecuária Brasileira, 43, 255-260. https://doi.org/10.1590/ S0100-204X2008000200015

Souza, E. D., Carneiro, M. A. C., Paulino, H. B., \& Silva, C. A., Buzetti, S. (2006). Frações do carbono orgânico, biomassa e atividade microbiana em um Latossolo Vermelho sob cerrado submetido a diferentes sistemas de manejos e usos do solo. Acta Scientiarum. Agronomy, 28(3), 323-329. https://doi.org/10.4025/ actasciagron.v28i3.940 
Trannin, I. C. B., Siqueira, J. O., \& Moreira, F. M. S. (2007). Características biológicas do solo indicadoras de qualidade após dois anos de aplicação de biossólido industrial e cultivo de milho. Revista Brasileira de Ciência do Solo, 31(5), 1173-1184. https://doi.org/10.1590/S0100-06832007000500032

\section{Copyrights}

Copyright for this article is retained by the author(s), with first publication rights granted to the journal.

This is an open-access article distributed under the terms and conditions of the Creative Commons Attribution license (http://creativecommons.org/licenses/by/4.0/). 